\title{
SOCIAL INNOVATION IN TOURISM: UNLEASHING THE TIME-MONEY CONSTRAINT
}

\section{Abstract}

This study aims to explore whether the time-money constraint in tourism can be exerted to foster unconventional social innovation in the tourism industry. This study builds its conceptual framework upon the concept of time banking as an alternative currency in spurring social innovation in the tourism economy. To explore the applicability of the concept in tourism, we investigated the intentions and needs of the supplier and consumer sides through interviews and focus groups. To explore the entrepreneurial perspective three in-depth interviews were conducted respectively with the co-founder of TimeRepublik, an independent social entrepreneur, and a sharing economy specialist. Three focus groups were also conducted to evaluate and elaborate the practical application of the framework from a user's point of view. We found that using time as a measure of work shows a potential to reconcile the time-money constraint especially for disadvantaged groups. However, this study has exposed discrepancies between the intentions and the needs of the social entrepreneurs and the users, undermining the feasibility of the concept in the tourism context. Namely, the challenges included the value of time, trust and relationship building, and network effects and scaling. As long as the innovation is unable to achieve inclusive and sustainable growth building upon its social values, the lack of user support will only lead to selected and limited application of the concept in tourism and therefore will fail to generate social benefits on a larger scale.

Keywords: Social innovation; time-money constraint; time bank; tourism; hospitality; sharing economy

Published in "Journal of the knowledge economy", 2019, vol. 10, pp. 1700-1719, which should be cited to refer to this work. DOI : 10.1007/s13132-018-0534-0 


\section{Introduction}

Social innovation has gained increasing attention as a wide range of societal problems have posed challenges not only to market participants but also to the society as a whole (Murray et al. 2010). These concerns include stark inequalities widening within societies globally, difficult transitions to adulthood, and happiness mismatch between increasing GDP and stagnating well-being and welfare (Mulgan et al. 2007). Addressing these concerns requires actions from the civic, public and private sectors to trigger social innovation as a driver of societal transformation (Murray et al. 2010; Howaldt and Kopp 2012). Social innovation can be a vehicle to address a wide range of profound social problems and concerns, especially in times of austerity (Hubert 2010). Not only have international and governmental institutions, such as the European Union and the Obama Administration, started to incorporate social innovation in policymaking (European Commission 2013; Smith 2014), private sector players also dedicate greater resources to harnessing social innovation and fostering social entrepreneurship in the business context.

While social innovation has received considerable attention, its application to the tourism sector is rare (Ball 2005). Yet, tourism can generate income for underdeveloped areas to alleviate poverty, and in addition create social capital for local communities (von der Weppen and Cochrane 2012; Okazaki 2008). This indicates that tourism is a viable arena for spurring social innovation. A variety of innovations in tourism to date have been limited to talent-development, sustainability, and eco-tourism initiatives, which can be called social entrepreneurship rather than social innovation (Ergul and Johnson 2011). Social innovation in tourism has become more elusive in recent years with the advent of the sharing economy in various tourism and hospitality sectors. Some argue that the sharing economy platforms, such as Airbnb and Couchsurfing, capitalize on the social capital of their users (Molz 2013; Schor and Fitzmaurice 2015), and therefore is the ultimate form of social innovation (Martin et al. 2015). Yet others argue that these business models undermine the essence of social innovation due to both their profit-oriented nature and the fallout from wide range of legal disputes from race discrimination to security and scams (Guttentag 2013; Edelman and Luca 2014).

Unlike other economic activities, tourism consumption and production are constrained by time and financial resources (Nyaupane and Andereck 2007). The time-money constraint, a tradeoff between having more leisure time and earning less by working less or vice versa, has chronically haunted consumers and scholars from the leisure society conceived by Veblen (1899) in the late 19th century to the digital age (The Economist 2014). Despite economic progress and various technological advances having considerably shrunk working hours over the past century to allow people to have more leisure time, the "perennial time-scarcity problem" still exists. Ironically, time is still pressing in today's society for wealthy people in developed countries, whose priority should be on leisure. The leisure society, where people enjoy more leisure time and work less, seems yet to emerge in the digital age, which runs contrary to what scholars predicted more than a century ago (The Economist 2014). The time-money constraint still determines the scale and the scope of tourism consumption as well as the extent to which tourism can affect the society as a whole (The Economist 2014; Godbey 2005).

We explore social innovation in tourism by grounding it on the time-money constraint as a fundamental premise. We aim to explore whether time and money, the two pronounced yet exclusive constraints for tourism activities, can be harnessed to spur social innovation that is specific to the tourism economy. Given the pivotal role of time and money in determining the consumption and production of tourism, we argue that time and money should be treated as resources instead of constraints from a social perspective. This study proceeds by first reviewing the literature on social innovation and social entrepreneurship as well as their relationship with the tourism economy. Second, we propose a framework that can incorporate time and money in non-market transactions by building upon the concept of time banking. Third, we provide evidence regarding whether and how time banking in tourism can reconcile the time-money constraint to generate social innovation in tourism.

\section{Literature Review}

\subsection{Definitions of social innovation}

Social innovation can be seen as a type of innovation that aims to resolve a social concern (Nicholls et al. 2015). The term social innovation first surfaced in Drucker's (1957) study, which defines it as a new management dimension that aspires to drive societal change by mass organizations. The Young Foundation, a research institute devoted to social innovation, defines social innovation as "innovative activities and services that are motivated by the goal of meeting a social need and that are predominantly developed and diffused through organizations whose primary purposes are social" (Mulgan et al. 2007, p. 8). This definition distinguishes social innovation from business innovations, as the former's goal is not profit maximization but resolving social issues. In public discourse, social innovation is often either confused or associated with corporate social responsibility (CSR) 
(Murray et al. 2010). The interchangeable use of these terms is misleading though, because social innovation is generally separated from a company's core activities and purpose (Mulgan et al. 2007), whereas CSR is usually seen as part of a company's business strategy (Danilovic et al. 2013).

Due to its elusive definitions, studies on social innovation are still scarce despite its implications being underscored by numerous studies (Pol and Ville 2009). Critics argue that social innovation is merely a buzzword unsuitable for academic research, since the evolution of the concept and a lack of established quantification methods have rendered it ambiguous and difficult to be empirically tested (Edwards-Schachter and Wallace 2017; Moulaert et al. 2013). However, this argument is generally refuted, as social innovation fundamentally distinguishes itself, through its specific altruistic purpose, from other types of innovations in the business context (Edwards-Schachter and Wallace 2017; Pol and Ville 2009).

\subsection{Social innovation and social entrepreneurship}

A similar concept to social innovation is social entrepreneurship, which is seen as a practitioner in social innovation that creates social values. Grounded in classic entrepreneurship, social entrepreneurship suggests that "the entrepreneur always searches for change, responds to it, and exploits it as an opportunity" Drucker (2015, p. 30). Social entrepreneurship is defined as opposed to conventional business entrepreneurs, and the differences lie in their goals (Martin and Osberg 2007). Business entrepreneurs aim to provide products that meet market demand in a financially efficient manner by creating values for themselves and investors, while social enterprises target "the creation of organizations and/or practices that yield and sustain social benefit" (Mair and Noboa 2006, p. 122). Similar to social innovation, social entrepreneurship can reach beyond the boundaries of the public, private and the civil sectors. However, social innovation is not limited to the realm of social entrepreneurship but stretches to encompass a wide range of social fields that may have little to do with entrepreneurship in a conventional business context (Phills et al. 2008).

Elkington and Hartigan (2008) identified three business models applicable to social enterprises, namely the leveraged non-profit, the hybrid non-profit, and the social business. The first model operates where a for-profit model is incapable of meeting a market need. The entrepreneurs characterized by this model, such as the Christian Habitat for Humanity, are often driven by ideological intentions and act as change-catalysts, which target sustainable long-term development. The second model aims to provide products or services to a market that is underserved by the mainstream economy. This model creates re-investable profit by blending business aspects and non-profit strategies. These enterprises, such as Aravind Eye Care System, are most favored by philanthropists. Hence, out of the three, the second model is putting the highest focus on experimental innovation. Social business ventures, the third business model, are for-profit businesses blending financial returns with social returns, allowing them to benefit from facilitated financing. The businesses, such as the Grameen Bank, target value generation, yet the chief goal is to create financial benefits for low-income groups, while sustainably growing the venture.

\subsection{Tourism and social innovation: a means to an end?}

Phills et al. (2008) argue that social innovation encompasses, connects and eventually depends on all sectors, ranging from the public, to the private and the non-profit or third sectors. Thus, it often requires a new combination or transformation of existing elements in all three sectors (Howaldt et al. 2015) to find a solution to social problems due to the market failure of all three sectors (Moulaert et al. 2013). Social entrepreneurship is particularly effective to improve the performance of an industry like tourism, which is characterized by low pay, hard working conditions and high labor turnover. Tourism is recognized as a promising field for studying social entrepreneurship due to its "potential for stimulating both social and financial added value along the supply chain" (von der Weppen and Cochrane 2012, p. 498). Tourism is arguably the "world's largest voluntary transfer of resources from rich people to poor people" (Mitchell and Ashley 2010, p.1), as tourists from high and upper-middle income countries are spending their vacation and money in developing destinations. Thus, developing tourism is a means to alleviate poverty through inclusive economic growth for countries whose economies depend highly on tourism.

Participants and stakeholders in the tourism industry have started to acknowledge their role in the community and have become more involved in social entrepreneurship activities (Ergul and Johnson 2011). Ergul and Johnson (2011) asserted that social entrepreneurship is generally associated with sustainability and environmental conscious projects, such as eco-tourism, community involvement and local donations. A crucial step to increase sustainability in the tourism industry was the introduction of the Global Code of Ethics for Tourism by the World Tourism Organization (UNWTO 2001), serving as a principal framework for responsible tourism. To provide industry standards and signal responsible practices, certifications such as Travelife or Certification of Global Sustainable Tourism have been created (Travelife 2017, GSTC 2017). Again, CSR initiatives of hospitality 
corporations should be differentiated from actual social entrepreneurship. Nevertheless, it is worth acknowledging that CSR in the hospitality sector is not always limited to superficial public relations stunts. Indeed, CSR has started to increase its influence on corporate decisions and their value chain (Bohdanowicz and Zientara 2008, 2009).

\subsection{Tourism and the sharing economy: social or disruptive innovation?}

The sharing economy has been seen as the ultimate social innovation (Martin et al. 2015), largely because it claims to reduce wastage by efficiently utilizing resources and creating social capital through sharing (Botsman and Rogers 2010). The motives of participants in the sharing economy include obtaining economical, sustainable, and social benefits (Schor and Fitzmaurice 2015). Especially for millennials, the sharing economy is a response not only to their restrained earning power but also to their increasing consciousness of the environment and desire for social connections (Martin 2016). Empirical evidence is lacking regarding whether the sharing economy is ecologically sustainable (Schor and Fitzmaurice 2015). Also, most sharing platforms fail to provide lasting social ties and the users tend to distrust other co-users (Bardhi and Eckhardt 2012). Not only firms but also users of the sharing economy seem to become more profit driven as the business model matures, leaving their social goals far behind (Eckhardt and Bardhi 2015). Whether the sharing economy can adequately address the grand social concerns is questionable as it becomes a social problem itself, exemplified by rampant tax aversion and race discrimination (Edelman and Luca 2014; Jefferson-Jones 2016; Martin et al. 2015; Martin 2016).

\section{Conceptual Framework}

\subsection{Tourism and the time-money constraints}

Time and money lie at the heart of the tourism economy, and therefore should be one of the focuses for entrepreneurs to implement social innovation. The aftermath of the recession in 2009 has exacerbated time-money constraints due to the decline in income and the rising unemployment rate in developed economies. This provides an opportunity to revisit the time-money constraint that has guided tourism production and consumption since the birth of the modern tourism industry in the mid-19th century. In doing so, it could lay a foundation for exploring social innovation in tourism. One of the social economy's initiatives is community currencies, aiming at facilitating non-cash exchange and functioning as a complement to the orthodox market economy (Collom et al. 2012; Seyfang 2004). In addition, it addresses a wide range of social concerns (Seyfang and Longhurst 2013), through promoting sustainable development of the community, supporting network building, increasing social capital, encouraging social inclusion and cohesion, as well as rewarding and enhancing civic engagement.

\subsection{Community currencies and time banking}

We begin with a popular type of community currency in the United States, called time credit, issued by time banks, which are "localized exchange systems based on time" (Collom et al. 2012, p.1). Time banks were established by Edgar Cahn in 1986 in the United States as a reaction to the erosion of neighborhood support and social networks (Seyfang 2006), and therefore have profound connotations for social innovation. The principle guiding the transaction of time is that for every hour a time bank member who provides a service to another member can receive one hour of service by anyone else in the community in return. The time bank values everyone's time equally, regardless of the skill-level of service performed in a specific amount of time (Collom et al. 2012). The principle of the time banking model can be translated into specific transaction rules as follows (Cahn 2004; Seyfang and Longhurst 2013).

- Participants report the services they need and can offer in return;

- Everyone agrees to provide and receive service;

- Participants earn one time credit per every hour of service provided; and

- One hour equals one time credit regardless of the skills or service provided (Timebanking 101 2017).

Cahn's (2004) goal was to create a win-win situation for the members of the market and non-market economy by introducing time credits as a parallel currency, allowing companies to expand their market, while people can increase their consumption without relying on public support. Cahn (2004) argued that the market assigned high value to scarce skills and abilities, while services which are necessary but commonly applicable, such as household work, are devalued. Time banks are seen as a social innovation on the grounds that it promotes reciprocal exchanges to combat poverty, exclusion, and unemployment (Avelino et al. 2014). By offering a spectrum of services ranging from the complex, such as language lessons, to simpler services, such as dog walking, but also personal services, including care-provision to the elderly, time banks allow its members to "pay for what you get 
by contributing according to your skills and abilities" (Avelino et al. 2014; Cahn 2004).

The social aspect to time banks is central, as Seyfang (2006) described time banks as a "social economy innovation which reward(s) participation in community activities or helping neighbors, and aim(s) to nurture social capital and networks of reciprocity" (p. 435). This allows communities to become more efficient in utilizing previously untapped resources. By providing a complimentary system to the market economy, Gregory (2009) found that time banks can ease participants' dependence on money, especially during times of austerity. Participants could also gain access to care-services and education, which may not be unavailable in the conventional marketplace, which requires money as the only transaction means. Collom et al. (2012) found that time banks appealed to the economically and socially disadvantaged whose finance, friendships or health are in jeopardy. Time banking can address a wide range of social concerns by improving social ties and trust, thus reducing exclusion and social marginalization (Collom et al. 2012).

\subsection{Time banking in tourism}

Despite time banking's potential to ease the time-money constraint by transforming time into a community currency, its impact on tourism remains underexplored. Our investigation begins with one typical example in a time bank, TimeRepublik, which is particularly relevant due to its involvement in tourism and hospitality. TimeRepublik, launched in 2015, describes itself as the ultimate sharing economy platform that applies the time banking concept to target an unlimited global user community. It is now present in over 110 countries and has over 100,000 users. It was featured in a documentary that followed a family traveling in Italy for half a year, exchanging services for food, transportation and lodging without spending any money (Basadonne et al. 2015). TimeRepublik aims to create a space where people can follow their passions and exchange their skills, using time, instead of money, as a currency. While initially the platform relied on funding to support itself, it recently introduced a new business model that includes licensing while white-labelling the platform to corporations who wish to boost employee engagement (TimeRepublik 2017)

In order to proceed with the empirical investigation of time banking in tourism, we build an analytical framework of time banking on the five core values outlined by Cahn (2004). These five core values are:

- $\quad$ Assets: People are the assets and wealth of a society. Time banking preserves the value of performed work through the " 1 hour=1 hour" principle.

- $\quad$ Redefining work: The market economy does not recognize certain social work in private households and communities of the non-market economy, yet they should be remunerated by some means.

- Reciprocity: Mutual support is more sustainable than one-sided help initiatives, since both sides benefit from it.

- Social capital: Social infrastructure is essential for communities and requires constant investment to generate trust, reciprocity and civic engagement.

- Respect: Every contribution is valued, yet feedback is vital for service improvement.

Figure 1 illustrates the relationships of these five core values that guided our empirical study that follows. We center on the role of time in measuring and exchanging for various tourism products and services (time as assets). Since time is equally possessed by all in the society, its value goes far beyond its monetary values in a conventional marketplace. It therefore becomes a ubiquitous measure for all activities (time redefines work), through which respect is established for both parties in an exchange (respect). In the time banking framework, not only is reciprocity established but it is also expended because of the universal asset of time possessed by all in the society (reciprocity). Social capital in the form of trust, mutual support and civic engagement is being accumulated when reciprocity is scaled up. 


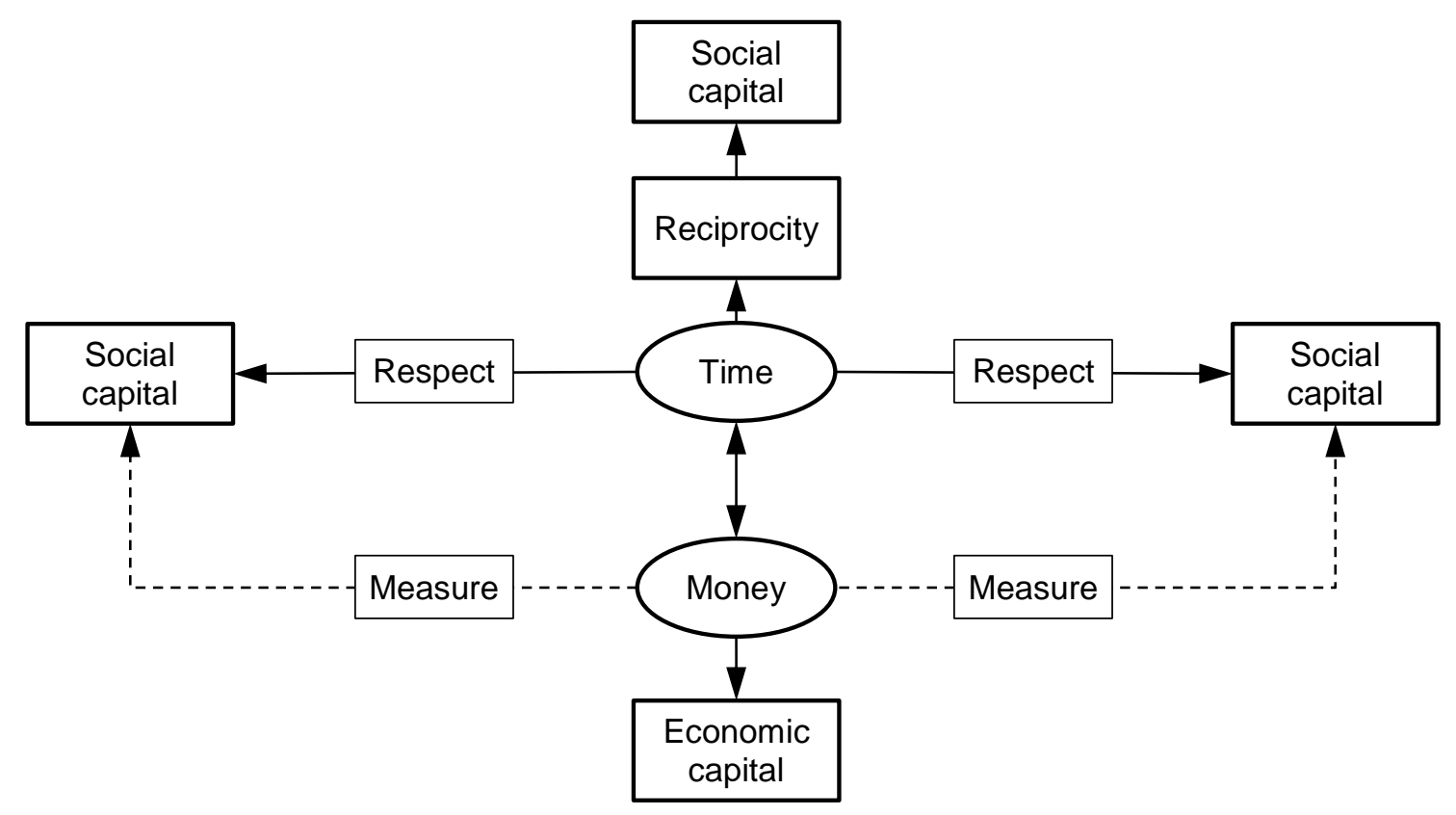

Figure 1. Analytical Framework

\section{Methodology}

\subsection{Research design}

To examine the opportunities of tourism in timebanking we decided to carry out a single case study on the sharing platform TimeRepublik. Other than conventional time banks, TimeRepublik is a global online platform, which is not limited to local communities. It offers worldwide exchange between members through the means of the Internet, whether it is on the platform itself or via third parties, such as Skype or Google Hangouts. For this reason, the enterprise offers the unique opportunity to explore and study in-depth the phenomena in a natural context. We aimed to explore the time bank framework in tourism by investigating its applicability from both supply and demand sides. This is because the time-money constraint is encountered by both, firms and consumers, and the relaxation of this constraint entails innovation. We adopted both in-depth interviews and focus groups to gather data and insights respectively from entrepreneurial participants and prospective users into the application of time banking in tourism. Therefore, the applicability of time banking depends not only on the intention of social entrepreneurs but also whether the users' well-being can be improved. To illustrate the interdependence of demand and supply, the interviews and focus groups were held in rotation. The initial focus group was set out to gather first impressions of users new to the concept. These were voiced to the founder, who then had the opportunity to justify his intentions. Subsequently, said arguments were again debated in the focus groups and with an independent social entrepreneur, allowing us to exchange and test the arguments among the parties.

\subsection{Data collection: in-depth interviews}

To explore the performance and test the potential of the tourism offer on TimeRepublik from an entrepreneurial perspective, three semi-structured interviews were conducted to elicit the insights from the users and the founder (Table 1). The first interview was conducted with Gabriele Donati, the co-founder of TimeRepublik. It aimed to explore the philosophy behind the platform, to compare the phenomenon to classic time banks, and to gather general information on its user behavior. Furthermore, the interview discussed the present application and future opportunities of the concept in tourism and travel.

Table 1. Interview Context

\begin{tabular}{llll}
\hline & Position & Research interest & Framework \\
\hline \multirow{2}{*}{ G. Donati } & Co-founder of TimeRepublik & $\bullet$ Performance and vision of & $\bullet$ Social capital and \\
& and social entrepreneur & TimeRepublik & respect \\
& & $\bullet$ Experience and potential of & $\bullet$ Measure (redefine \\
\hline
\end{tabular}




\begin{tabular}{|c|c|c|c|}
\hline & & tourism on TimeRepublik & work) \\
\hline N. Vuong & $\begin{array}{l}\text { Web consultant and social } \\
\text { entrepreneur }\end{array}$ & $\begin{array}{l}\text { - Entrepreneurial potential of } \\
\text { TimeRepublik } \\
\text { - Social entrepreneurship in the } \\
\text { sharing economy }\end{array}$ & $\begin{array}{l}\text { - Economic capital and } \\
\text { reciprocity } \\
\text { - Measure (redefine } \\
\text { work) }\end{array}$ \\
\hline P. Villars & Sharing economy specialist & $\begin{array}{l}\text { - Test TimeRepublik's fit in the } \\
\text { sharing economy } \\
\text { - Development of social } \\
\text { innovation in the sharing } \\
\text { economy }\end{array}$ & $\begin{array}{l}\text { - Social capital and } \\
\text { respect } \\
\text { - Economic Capital and } \\
\text { reciprocity }\end{array}$ \\
\hline
\end{tabular}

The second interview was conducted with Nhat Vuong, a web marketing consultant and social entrepreneur. This interview aimed to get an independent expert opinion on the platform and its concept, mainly to analyze the attractiveness and the user friendliness of the concept and web page directly. The two interviews were conducted with Skype on May 17 and 22, 2017, lasting 54 and 38 minutes respectively. Semi-structured with open-ended and probing questions were used to facilitate the interviews.

The third interview was conducted on May 16, 2017 in writing via email with Pablo Villars, a master's student from the University of Geneva specialized in the sharing economy, with a focus on the regulation of Airbnb in Switzerland. This interview was structured with open-ended questions, which were based on the analytical framework. It aimed at analyzing the concept's position within the sharing economy and to assess the social innovation aspect of the sharing economy in general. The questions were adapted to each interview according to the expertise of the interviewee and included open-ended and probing questions.

\subsection{Data collection: focus groups}

Three focus groups were conducted 1) to evaluate the general acceptance of the time banking concept of the participants, 2) to explore the potential application of the concept in tourism and travel and 3) to analyze risks and limitations of its implementation. Focus groups are effective in generating varied and complex inputs (Liamputtong 2011), which can enable in-depth discussion on specific topics, examining opinions, experiences, concerns, and needs of the participants. By using a convenient sampling procedure, we selected 17 final-year students from our institution, with 10 females and 7 males. The participants aged between 21 and 26 years and were from Switzerland $(n=6)$, Taiwan $(n=3)$, Mainland China $(n=2)$, France $(n=2)$, Singapore $(n=1)$, Portugal $(n=1)$, Romania $(n=1)$ and Russia $(n=1)$. We then randomly divided the participants into three groups, with each group having 5 or 6 students. The three group interviews were conducted on May 17, 19 and 23, 2017 respectively on campus, each lasting between 20 and 30 minutes. Prior to each group interview, the participants were introduced to the concept by a handout and were subsequently asked structured open questions and spontaneous probing questions.

\subsection{Analysis}

The transcripts of the in-depth interviews were coded and analyzed by using the qualitative research methods from Given (2008). The methods used for the focus group preparation, conduction, and thematic analysis, including coding and categorization of the transcripts, was adapted from Liamputtong (2011). First the audio transcripts underwent initial coding to label and loosely categorize the responses. Second, the various categories were combined or subdivided during the focused coding, according to the frequency and prominence of the statements. Third, the final coding categories were selected given their reoccurrence during the in-depth interviews and focus groups, as well as their relevance to the analytical framework (Figure 1). As a result, the interviews were structured and discussed under three categories outlined by the framework as well as two categories that have particular relevance to the sharing economy and social innovation: (1) Measure: redefining work and the value of time; (2) Economic capital and reciprocity: market dynamics and network effects; (3) Social capital and respect: relationships and trust in time banking trust and relationships; (4) Time banking in the sharing economy; and (5) time banking and social innovation in tourism. The results of the focus groups were structured in the same categories and set out to test the statements in the interviews.

\section{$5 \quad$ Results and Discussion}

We aimed to explore the opportunities and challenges for the time banking platform in the tourism context. In what follows we present and interpret the opinions from both the in-depth interview and focus group participants, which can help examine whether the concept has the potential to yield a viable social innovation in tourism. 


\subsection{Measure: redefining work and the value of time}

Donati explained that TimeRepublik is not concerned with measuring the value of its users' skills, but to build relationships between people. The founder justified the " 1 hour $=1$ hour" principle using the following short story about a plumber and a surgeon, through which he articulated his perspective on the subjective and situational values of time.

A simple plumber is invited to the party of his friend, a high-income, well trained surgeon. While everyone is enjoying the party, suddenly a pipe bursts and the kitchen is getting flooded. In this situation, whose skill is more valuable?

Controversially, Vuong claimed that the concept was unrealistic as activities could have a completely different value that can be defined for most situations.

Vuong: I could have the same argument and say a bottle of water would be more precious than a diamond in the desert. Yes of course, depending on the situation, but still I think the majority of the time they (the skill of the plumber and the surgeon) still have pretty different values.

However, TimeRepublik's " 1 hour $=1$ hour" principle was highly debated among the focus groups participants. Interestingly, several participants wondered whether time credits could be bought with money. Most participants did not perceive it as fair that a high-skill service should be valued equally to a low-skill service and suggested introducing categories according to the activity performed.

P3.3: Walking the dog and then tutoring someone is different, right? Like walking a dog is something anyone could do, but you have to acquire knowledge before you can actually teach it.

P1.4: If you give (...) let's say language lessons, I kind of want money for it, not an hour.

Other participants, albeit not many, agreed with the basic " 1 hour $=1$ hour" ideology.

P2.1: One hour of the life of someone is exactly like one hour of the life of someone else, no matter the skills.

Eventually, one participant argued that the value perception of a service is dependent on the specific situation of the person who was requiring the service.

P3.1: I think the value is in the eyes of the guy who asks (for the service). If you really need the dog walking because you really cannot do it, it's going to be valuable to you. So, you cannot just say one hour of dog walking is not the same as one hour of tutoring.

\subsection{Economic capital and reciprocity: market dynamics and network effects}

Donati claimed that TimeRepublik does not try to replace monetary exchanges, but offers a complimentary system to the market economy, leveraging another dynamic. Donati explained that the founders do not want the platform to follow the drivers of the market economy, indicating that they were not obsessed with rapidly expanding their user base at all cost. According to Donati, drastic growth is neither healthy nor sustainable, as it results in pressure to maximize profit. Eventually, rapid growth could threaten the community and the egalitarian ideology of TimeRepublik, as the mainstream might not accept the "1 hour $=1$ hour" principle.

When confronted with the strategy of growing slowly, Vuong suggested that the idea of licensing and maintaining the website, while not being able to present a growing, well-functioning community and platform, appeared to be overly optimistic to him.

Vuong: He needs to advertise it a bit and see if the idea catches on with people. (...) You can have great intentions but if nobody uses it, then it's not going to happen.

Villars confirmed that usually ideologically driven companies in the sharing economy progressively become profit-driven like conventional businesses. However, he remarked that this should not implicitly be seen as a zerosum game, since the interest of the platforms is often in line with the user demands.

The focus group participants, on the other hand, believed that this concept could gain traction as they had heard of similar successful systems built on social relationships and exchange. Yet the participants expressed concerns that 
as the network grows it could become more difficult to maintain trust within the community, rendering it prone to misuse and cheating.

P3.3: If I provide one hour of service is there actually going to be something or someone timing me? Or is it like: "Hey I do 30 minutes" and I can bounce and then no one would know actually, validly (if I did it)?

The majority of the focus group participants were not convinced that the concept would be successful in the long run, as they found it unlikely to spark enough interest to be adopted by the masses of users.

P1.2: I think society today, the way it is made; it is going to be very hard for a concept like this to get mainstream. (...) People are too focused on what the revenue and the value is.

In order for Donati's vision of a more helpful and connected society to become a reality, the platform would have to attract users with a market mind-set at a certain point. The focus group participants were willing to share their services only if they could find satisfactory offers in return. This demand is in line with Shih et al. (2015), who assert that time banking relies on the network effects. In order to facilitate a fluent, reciprocal exchange, it is fundamental for a platform of such kind to provide a broad range of offers that appeal to its users. Not reaching beyond the early adopters to satisfy the diverse demands of an early majority could eventually lead the company to fall into the chasm, ending up with a shrinking user base, similar to many conventional community currency initiatives (Seyfang and Longhurst 2013; Moore 2014)

Yet Donati and the focus group participants were also cautious about scaling, as it could weaken the community, making it prone to abuse, and endangering the egalitarian values of the platform (Winikoff 2017). Considering Villars' comment that matured companies often transfer their ideological motif to a more profit-driven business model, an observation shared by Schor and Fitzmaurice (2015), Donati's concerns could be justified. It turns out that it is difficult for ideologically driven platforms like TimeRepublik to withstand the market dynamics as it grows and matures. However, as Villars mentioned, this is not necessarily a negative development. Even with a for-profit model the platform can still be seen as a type of social enterprise, namely a social business venture (Elkington and Hartigan 2008).

\subsection{Social capital and respect: relationships and trust in time banking}

Donati understands that TimeRepublik is not just as a simple platform, but more an ice-breaker to develop social capital by building new relationships through organic collaborations and mutual help of like-minded people. Donati sees himself as a social entrepreneur with the strong ideological mission to relieve the lack of trust, one of the major problems of today's society. In his opinion, trust can be forged through establishing relationships only, instead of financial means. For Donati, the main difference between money and time is that the former is used for facilitating transactions, while the latter is used for building relationships.

Donati: Our ultimate goal, (...) is really to try to scale empathy, dignity and trust with TimeRepublik, through service exchange, which is the beginning, in order to create relationships between people.

Vuong acknowledged that helping was a basic human desire. However, he was not convinced whether an exchange of service charged through time was not still a simple business transaction, even when money is omitted.

Vuong: At the end, we want to help each other and we're happy to do some free stuff for your friend and things like that. When it becomes more transactional, do you lose (...) emotions and gratefulness, (...) the human side of it? Isn't there something that is lost that you don't get back by using such a website?

Looking specifically at TimeRepublik, the focus group participants were concerned about the spectrum, quality and reliability of the service provided. For some users, a lack of money rendered the incentive of the transaction too low to be reliably respected by the users. TimeRepublik's public reviewing system was only regarded as partially effective, since it cannot contain damage that already occurred. Time wasted on unsatisfactory services ultimately remains non-refundable. When being asked, whether they believed that the exchange of time would yield a better relationship among co-users than that of money, the focus group participants generally said no.

P3.1: No, because it is still a service. It's still: "I owe you something; you owe me something in exchange". It's less of a hassle, because there is no money involved but it's still something. 
Travel community platforms, such as Couchsurfing, are built upon relationships (Picard and Buchberger 2013). While the founder of TimeRepublik claims that unlike money, an exchange of time leads to a relationship and not a transaction, both the focus group participants and Vuong challenged this argument. They argue that a time-based trade is still a market transaction and does not automatically amplify the social capital of the involved parties. Previous studies with actual time bank members suggest that the exchanges were indeed seen as more cordial, yet the research does not indicate whether these interactions resulted in actual social relationships (Dubois et al. 2014). Recalling the comments of the focus group participants who affirmed using Couchsurfing to experience the local lifestyle, but denied using sharing platforms to get to meet new people, it can be debated whether users are generally more interested in increasing their cultural capital than building lasting relationships with co-users in the sharing economy.

\subsection{Time banking in the sharing economy}

Donati saw TimeRepublik as the "ultimate sharing platform", as it can completely unleash the power of the sharing economy, such as Airbnb and Uber, through time exchange. He further argued that the time-based platform is in line with today's generation, who care more about sharing experiences while less about possessing a resource that generates the experiences. Donati articulated the difference between TimeRepublik and conventional time banks from a perspective of global community. The difference is that most of the members worked freelance and offered computer, literacy or tutoring services worldwide.

Donati: We started as a time bank, but today we look at ourselves more like a global working space that owns no space.

Vuong agreed that younger generations have started to see value in sharing and exchanging instead of owning and consuming things, especially when their budgets are increasingly tighter. In his view, the concept makes sense in the development of the sharing economy; however, Vuong was skeptical about whether mainstream users would accept this new business model.

Villars suggested that the time bank concept is radical, yet similar platforms building upon intangible and affective values, such as Couchsurfing, have proven successful in the sharing economy. In his opinion, the sharing economy has the potential to relieve several social concerns and increase social welfare. Villars stated that to sell successfully, the social commitment of the sharing platforms is still vital. The social dedication component could be partially fulfilled by marketing activities, however, without a sincere core, it is not credible.

A majority of the focus group participants reported having used sharing platforms such as Airbnb, Uber and, a selected few, Couchsurfing. The main reasons for choosing the sharing platforms included the price-value advantage and availability.

\section{P1.2: Usually you find a place at the center of the city which is way cheaper than the hotel}

is.

Considering travel platforms, several participants, especially Couchsurfing users, further claimed that their choice was made due to a desire for a more authentic and local experience.

\section{P1.4: You bring something and usually they're really helpful and nice, and they show you around.}

I've had really good experiences. (...) We also hosted people.

Yet the participants broadly negated using the sharing economy to meet new people and build relationships with strangers. In fact, whether they can trust others or to be trusted by others was among the biggest concerns in using the sharing platforms.

\section{P2.3: Depending where you go it can be risky to stay with strangers (on Couchsurfing). Even when I book Airbnb, I do not book rooms but the whole apartment.}

While similar to the dominant sharing economy platforms, such as Airbnb and Uber, TimeRepublik claims to be the ultimate sharing economy experience through time exchange instead of money. However, the focus group participants underscored financial motivators when considering engaging in the sharing economy. The social and ideological values of the sharing platforms like Couchsurfing also spurred their interest, confirming the statement of Villars. Building upon these benefits, time banking could offer a better alternative as it allows inclusive travel experiences, while avoiding the abuse of the scheme through freeloaders, found on Couchsurfing (Lauterbach $e t$ 
al. 2009). One participant pointed out that platforms such as Workaway or helpStay, featuring hostels that offer free stays in return for work or volunteering, are among the most popular options for budget travelers with altruistic motives and an interest in authentic cultural immersion. The success of these platforms indicates that the market for TimeRepublik is feasible.

\subsection{Time bank and social innovation in tourism}

When being asked whether users request or offer lodging on TimeRepublik, Donati recalled a bed and breakfast in Rome, which allows its guests to pay with time and charges six hours per night. He admitted that the exchange quickly became complicated when it came to inn-keeping.

Donati: It's hard because when you're renting your house for two days you cannot really charge for 48 hours.

According to Donati, tour guiding services and lifestyle travel activities are among the most commonly used services for TimeRepublik users, as they are easier to deliver and require a lower level of trust and acquaintance.

Donati: It is pretty popular the tour guide and life style guide. (...) It's a great way to go to meet people and to take them around and to establish again, I am never tired enough to say the word, a relationship.

Yet Donati sees a potential for the time bank to incorporate tourism and hospitality services in the coming years as the community grows stronger, especially due to the success of other sharing accommodation platforms, such as Airbnb and Couchsurfing. His view was shared by Villars. However, Donati voiced caution due to the ongoing disputes between Airbnb and traditional hospitality businesses.

Several focus group participants had heard of sharing platforms similar to TimeRepublik in tourism and hospitality, including free walking tours, work and stay hostels or table sharing. Table 2 lists a range of conceivable tourist activities and specifies several comparable platforms. Additionally, it illustrates the posed opportunities and the challenges faced by TimeRepublik as examined by the interviews and focus groups.

Table 2. Managerial Implications

\begin{tabular}{|c|c|c|c|}
\hline & Existing offer & Opportunity & Challenges \\
\hline Inn-keeping & $\begin{array}{l}\text { Airbnb, } \\
\text { Couchsurfing }\end{array}$ & $\begin{array}{l}\text { Demand for authentic, } \\
\text { colloquial and inexpensive } \\
\text { stay }\end{array}$ & $\begin{array}{l}\text { Measure: } \\
\text { - Define worth of hours of } \\
\text { sleep and work }\end{array}$ \\
\hline $\begin{array}{l}\text { Tour guide and } \\
\text { life style }\end{array}$ & $\begin{array}{l}\text { Big Apple Greeters, } \\
\text { Airbnb Experiences }\end{array}$ & $\begin{array}{l}\text { Demand for original and } \\
\text { unique experience }\end{array}$ & $\begin{array}{l}\text { - Define worth of different } \\
\text { skill or facility category }\end{array}$ \\
\hline $\begin{array}{l}\text { Sharing meals and } \\
\text { drinks }\end{array}$ & $\begin{array}{l}\text { MealSharing, } \\
\text { EatWith }\end{array}$ & $\begin{array}{l}\text { Interest in real local food } \\
\text { and new tastes }\end{array}$ & $\begin{array}{l}\text { Economic capital and } \\
\text { reciprocity: }\end{array}$ \\
\hline Transportation & Uber, BlablaCar & $\begin{array}{l}\text { Demand for inexpensive, } \\
\text { reliable, and efficient } \\
\text { transportation }\end{array}$ & $\begin{array}{l}\text { - Dependent on network } \\
\text { effect (scale) } \\
\text { - Fit between offer and }\end{array}$ \\
\hline Part-time jobs & $\begin{array}{l}\text { WorkAway, helpX, } \\
\text { HelpStay }\end{array}$ & $\begin{array}{l}\text { Demand for work } \\
\text { possibilities during stay }\end{array}$ & $\begin{array}{l}\text { demand range } \\
\text { Social capital and respect: }\end{array}$ \\
\hline $\begin{array}{l}\text { Employee } \\
\text { engagement }\end{array}$ & $\begin{array}{l}\text { Various CRS } \\
\text { activities }\end{array}$ & $\begin{array}{l}\text { Interest of enterprises to } \\
\text { engage associates through } \\
\text { volunteering and leisure } \\
\text { activities }\end{array}$ & $\begin{array}{l}\text { - Lack of monetary } \\
\text { incentives } \\
\text { - Quality control and } \\
\text { reliability }\end{array}$ \\
\hline
\end{tabular}

The participants favored the tour guiding services as an easy way to get semi-professional introduction to local experiences. Considering inn-keeping, they identified the same challenge as Donati did, arguing that it is disproportionate to value, for instance, one hour of sleep equals one hour of work. One solution proposed by the participants was to charge a fixed amount of time per night and introduce different categories of lodging by facilities and services offered. It follows that the host could charge the guest by the services category, allowing the users to exclude unwanted services as well as avoid slipping into a negative balance by staying too many hours.

The focus group participants concluded that they were willing to participate in the time bank and offer services only if they were assured to have their needs met in return. They were not convinced whether there are a sufficient 
number of users willing to offer services, such as inn-keeping or tour guide. Also, they questioned whether these services would be of equal quality when provided by different people in different places. Furthermore, they were wondering how the time bank would be able to deal with group users in a situation where sharing and splitting the number of hours when traveling together is needed. The participants cautioned that TimeRepublik would face restrictions, similar to Uber and Airbnb, if it would grow to a larger scale. In addition, the participants did not point out the disruptive nature of the time bank, wondering whether the time bank, like other sharing economy platforms, could jeopardize salaried jobs in the destination economy that has long been dependent on the traditional tourism industry.

\section{Conclusion}

Social innovation has been barely touched on in tourism despite the fact that the tourism industry itself has the capability to create social and cultural capital and boost societal prosperity. Going beyond the common eco and sustainability initiatives in the tourism industry, we explored a radical approach to social innovation by centering on the relationship between time and money, the two fundamental constraints of tourism activities. Building upon the time bank concept and the practice of TimeRepublik, we explored the possibility of time as a universal measure of work and services in tourism that can reconcile the time-money constraint. If possible, it can not only harness the power of tourism in increasing social welfare but also incorporate a large scale community to achieve inclusive and sustainable growth. However, our study has shown that social entrepreneurs and users, representing the two sides of an economy, disagree on a lot of issues that underpin the time bank concept and the initiative of TimeRepublik. While these disagreements apply to the sharing economy as a whole and are not exclusive to the time bank concept, they potentially undermine the feasibility of this concept.

Underlying the time bank framework is the central role of time in facilitating transactions and building relationships. The universal measure of time that redefines different categories of work and services is exemplified by the "1 hour $=1$ hour" principle, which values everyone's work equally, regardless of the nature or skill-level of the work performed (Cahn 2004). This makes time credits the ideal tool, from a social equity point of view, with which to combat social exclusion, ease financial duress, and strengthen the local community. For this reason, time banks are particularly effective in generating welfare and encouraging self-help for economically deprived communities. Nevertheless, the " 1 hour $=1$ hour" rule seems to resonate only with a limited number of early adopters who value egalitarianism and altruism more than economic performance and efficiency. Thus, if the time bank aims to expand its user base beyond early adopters it may need to convince the mainstream users to adapt a more altruistic philosophy. However, it is improbable in the foreseeable future. A second solution would be to rely on the market to determine the price of different services, and therefore determine their values.

While ideological and altruistic values are embraced by social entrepreneurs in our in-depth interviews, there are indications that the time bank starts to progressively mimic the market economy by gradually segregating users and activities that vary by skill levels. Trust and relationship building was also questioned by the focus group participants as the major motivation of participating in the platform. Generally, previous research has affirmed that a social motivation tends to be present when using time sharing platforms; however, similar to conventional time banks it is often translated in the desire to develop the individual cultural capital rather than building lasting relationships. Our study seems to reaffirm this trend as the interest in the time bank is not necessarily driven by the proposition of relationship building, similar as in other sharing platforms. This raises further questions on whether the time bank's main purpose of trust and relationship building in an online community truly serves a dominant and imminent need of today's society. Regardless, the time bank platform that is expected to accumulate social capital through trust building and reciprocity may fall behind in fulfilling its goals as the ultimate embodiment of the sharing economy.

For any sharing economy platform that is based on an interactive online community, network effects determine the success of the platform and remain one of the pillars of the sharing economy. Our study has shown that the participants were skeptical about whether the time bank can attract enough service providers to trigger network effects. While the time banking system seems simple at first, its application to the tourism sector could face several challenges. Topics discussed, such as the number of hours charged per night or the fear of staying at a stranger's place mirrored concerns regarding value of time and trust. Yet, tour guide and lifestyle services were generally perceived well and show the best potential for development. However, for the concept to be attractive to a broader market, it would have to drastically increase its user base.

Through time trading, the initiative of TimeRepublik could enable people with constrained financial means to enjoy a wide variety of tourism and hospitality services, and therefore extend the scale and scope of the tourism economy. As a social enterprise, TimeRepublik can bridge sectoral boundaries by involving cities, universities, 
businesses and non-profit organizations alike, creating a global community aspiring to create social capital through sharing and exchanging. However, for underdeveloped tourism economies that depend heavily on tourism to alleviate poverty, altruism and time are not, alone, capable of generating sufficient profits/income for local populations. This Innovation is unable to achieve inclusive and sustainable growth, and its social values will be questioned. Due to a lack of support from users, some see the time bank more as an experimental concept than a burgeoning corner of the economy capable of generating social benefits to a broader society. Whether the time bank concept will turn out to be a sustainable social innovation, scaling trust and relationships in today's society, can only be proven over time. 


\section{References}

Avelino, F., Wittmayer, J., Haxeltine, A., Kemp, R., O’Riordan, T., Weaver, P., et al. (2014) Game-changers and transformative social innovation: The case of the economic crisis and the new economy. TRANSIT working paper 1. TRANSIT: EU SSH.2013.3.2-1 Grant agreement no: 613169.

Ball, S. (2005). The Importance of entrepreneurship to hospitality, leisure, sport and tourism. Hospitality, Leisure, Sport and Tourism Network.

Bardhi, F., \& Eckhardt, G. M. (2012). Access-based consumption: The case of car sharing. Journal of Consumer Research, 39(4), 881-898.

Basadonne, L., Pollio, A., \& Basadonne, G. (2015). Unlearning. [Motion Picture]. Italy: Enter-tain Genova.

Bohdanowicz P., \& Zientara, P. (2008). Corporate social responsibility in hospitality: Issues and implications. A case study of Scandic. Scandinavian Journal of Hospitality and Tourism, 8(4), 271-293.

Bohdanowicz, P., \& Zientara, P. (2009). Hotel companies' contribution to improving the quality of life of local communities and the well-being of their employees. Tourism and Hospitality Research, 9(2), 147-158.

Botsman, R., \& Rogers, R. (2010). What's mine is yours: How collaborative consumption is changing the way we live. London: Collins.

Cahn, E. S., \& Barr, N. (1986). Service credits: A new currency for the welfare state. London: The London School of Economics and Political Science.

Cahn, E. S. (2004). No more throw-away people: The co-production imperative (2nd ed.). Washington, DC: Essential Books.

Collom, E., Lasker, J. N., \& Kyriacou, C. (2012). Equal time, equal value: Community currencies and time banking in the US. Burlington, VT: Ashgate Publishing.

Danilovic, M., Hensbergen, M., Hoveskog, M., \& Zadayannaya, L. (2013). Exploring diffusion and dynamics of corporate social responsibility. Corporate Social Responsibility and Environmental Management, 22(3), 129-141.

Drucker, P. (1957). Landmarks of tomorrow: A report on the new post-modern world. New York, NY: Harper \& Row Publisher.

Drucker, P. (2015). Innovation and entrepreneurship. New York, NY: Routledge. (Original work published 1985)

Dubois, E. A., Schor, J. B., \& Carfagna, L. B. (2014). New cultures of connection in a Boston time bank. In J. B. Schor \& C. J. Thompson (Ed.), Sustainable lifestyles and the quest for plenitude (pp. 95-123). New Haven, CT: Yale University Press.

Eckhardt, G. M., \& Bardhi, F. (2015, January 28). The sharing economy isn't about sharing at all. Harvard Business Review. Resource document. https://hbr.org/2015/01/the-sharing-economy-isnt-about-sharingat-all. Accessed 27 April 2017.

Edelman, B., \& Luca, M. (2014). Digital discrimination: The case of Airbnb.com. Harvard Business School NOM Unit Working Paper (14-054).

Edwards-Schachter, M., \& Wallace, M. L. (2017). 'Shaken, but not stirred': Sixty years of defining social innovation. Technological Forecasting \& Social Change, 119, 64-79.

Elkington, J., \& Hartigan, P. (2008). The power of unreasonable people: How social entrepreneurs create markets that change the world. Boston, MA: Harvard Business Press.

Ergul, M., \& Johnson, C. (2011). Social entrepreneurship in the hospitality and tourism industry: An exploratory approach. Consortium Journal of Hospitality \& Tourism, 16(2), 40-46.

European Commission. (2013). Towards social investment for growth and cohesion-including implementing the European Social Fund 2014-2020 (COM(2013) 83 final). Brussels.

Given, L. (2008). Semi-structured interview. The SAGE encyclopedia of qualitative research methods. London: SAGE Publications Ltd.

Germann Molz, J. (2013). Social networking technologies and the moral economy of alternative tourism: The case of Couchsurfing.org. Annals of Tourism Research, 43, 210-230.

Godbey, G. (2005). Time as a constraint to leisure. In E. L. Jackson (Ed.), Constraints to leisure (pp. 185-200). Pennsylvania, PA: Venture Publishing.

Gregory, L. (2009). Spending time locally: The benefit of time banks for local economies. Local Economy, 24(4), 323-333.

GSTC (2017). What is the GSTC? Resource document. https://www.gstcouncil.org/about/about-us/. Accessed 10 October 2017.

Guttentag, D. (2013). Airbnb: disruptive innovation and the rise of an informal tourism accommodation sector. Current Issues in Tourism, 18(12), 1192-1217.

Howaldt, J., \& Kopp, R. (2012). Shaping social innovation by social research. In H. W. Franz, J. Hochgerner \& J. Howaldt (Ed.), Challenge social innovation (pp. 43-55). Berlin: Springer.

Howaldt, J., Kopp, R., \& Schwarz, M. (2015). Social innovations as drivers of social change. In A. Nicholls, J. 
Simon, M. Gabriel \& C. Whelan (Ed.), New frontiers in social innovation research (pp. 32-35). London: Palgrave Macmillan UK.

Hubert, A. (2010). Empowering people, driving change: Social innovation in the European Union. Bureau of European Policy Advisers. Brussels. Resource document. https://ec.europa.eu/migrantintegration/index.cfm?action=media.download\&uuid=2A18225B-A4EF-443D-9D074439D071447D. Accessed 30 January 2017.

Jefferson-Jones, J. (2016). Shut out of Airbnb: A proposal for remedying housing discrimination in the modern sharing economy. SSRN Scholarly Paper No. ID 2772078, Rochester, NY: Social Science Research Network. Retrieved from http://papers.ssrn.com/abstract $=2772078$

Lauterbach, D., Truong, H., Shah, T., \& Adamic, L. (2009). Surfing a web of trust: Reputation and reciprocity on Couchsurfing.com. International Conference on Computational Science and Engineering 2009, IEEE.

Liamputtong, P. (2011). Focus group methodology: Principles and practice. London: SAGE Publications Ltd.

Mair, J., \& Noboa E. (2006). Social entrepreneurship: How intentions to create a social venture are formed. In J. Mair, J. Robinson \& K. Hockerts (Ed.), Social entrepreneurship (pp. 121-135). Hampshire: Palgrave Macmillan.

Martin, C. J., Upham, P., \& Budd, L. (2015). Commercial orientation in grassroots social innovation: Insights from the sharing economy. Ecological Economics, 118, 240-251.

Martin, C. J. (2016). The sharing economy: A pathway to sustainability or a nightmarish form of neoliberal capitalism? Ecological Economics, 121, 149-159.

Martin, R. L., \& Osberg, S. (2007). Social entrepreneurship: The case for definition. Stanford Social Innovation Review, 5(2), 29-39. Resource document. https://ssir.org/articles/entry/social_entrepreneurship_the_case_for_definition. Accessed 15 February 2017

Mitchell, J., \& Ashley, C. (2010). Tourism and poverty reduction: Pathways to prosperity. London: Earthscan.

Moore, G. A. (2014). Crossing the chasm: Marketing and selling disruptive products to mainstream customers (3rd ed.). New York, NY: HarperCollins Publishers.

Moulaert, F., MacCallum, D., Mehmood, A., \& Hamdouch, A. (2013). The international handbook on social innovation: Collective action, social learning and transdisciplinary research. Cheltenham: Edward Elgar Publishing.

Mulgan, G., Tucker, S., Ali, R., \& Sanders, B. (2007). Social innovation: What it is, why it matters, how it can be accelerated. Oxford: Saïd Business School, University of Oxford. Resource document. https://www.sbs.ox.ac.uk/faculty-research/skoll/research/social-innovation-reports-resources/socialinnovation-what-it-why-it-matters-and-how-it-can-be-accelerated. Accessed 20 March 2017.

Murray, R., Caulier-Grice, J., \& Mulgan, G. (2010). The open book of social innovation. London: The Young Foundation. Resource document. http://youngfoundation.org/publications/the-open-book-of-socialinnovation/. Accessed 15 January 2017.

Nicholls, A., Simon, J., Gabriel, M., \& Whelan, C. (2015). New frontiers in social innovation research. London: Palgrave Macmillan UK.

Nyaupane, G. P., \& Andereck, K. L. (2007). Understanding travel constraints: Application and extension of a leisure constraints model. Journal of Travel Research, 46(4), 433-439.

Okazaki, E. (2008). A community-based tourism model: Its conception and use. Journal of Sustainable Tourism, 16(5), 511.

Phills, J. A. Jr., Deiglmeier, K., \& Miller, D. T. (2008). Rediscovering social innovation. Stanford Social Innovation Review, 6(4), 34-43. Resource document. https://www.gsb.stanford.edu/facultyresearch/publications/rediscovering-social-innovation. Accessed 12 February 2017.

Picard, D., \& Buchberger, S. (2013). Couchsurfing cosmopolitanisms: Can tourism make a better world? Bielefeld: Transcript Verlag.

Pol, P., \& Ville, S. (2009). Social innovation: Buzz word or enduring term? Journal of Socio-Economics, 38(6), $878-885$.

Schor, J. B., \& Fitzmaurice, C. J. (2015). Collaborating and connecting: The emergence of the sharing economy. In L. Reisch \& J. Thøgersen (Ed.), Handbook of research on sustainable consumption (pp. 410-425). Cheltenham: Edward Elgar Publishing.

Seyfang, G. (2004). Working outside the box: Community currencies, time banks and social inclusion. Journal of Social Policy, 33(1), 49-71.

Seyfang, G. (2006). Harnessing the potential of the social economy? Time banks and UK public policy. International Journal of Sociology and Social Policy, 26(9/10), 430-443.

Seyfang, G., \& Longhurst, N. (2013). Growing green money? Mapping community currencies for sustainable development. Ecological Economics, 86, 65-77.

Shih, P. C., Bellotti, V., Han, K., \& Carroll, J. M. (2015). Unequal time for unequal value: Implications of differing motivations for participation in timebanking. CHI '15 Proceedings of the 33Rd Annual ACM 
Conference on Human Factors In Computing Systems, 1075-1084.

Smith, M. (2014, March 3) Innovation to impact: Obama’s Social Innovation Fund at four. Stanford Social Innovation Review. Resource document.

https://ssir.org/articles/entry/innovation_to_impact_obamas_social_innovation_fund_at_four. Accessed 2 March 2017

The Economist. (2014, December 20). Why is everyone so busy? Time poverty is a problem partly of perception and partly of distribution, The Economist Christmas Special. Resource document. https://www.economist.com/news/christmas-specials/21636612-time-poverty-problem-partly-perceptionand-partly-distribution-why. Accessed 11 October 2017.

Timebanking 101 (2017). Timebanks USA. Retrieved from http://timebanks.org/timebankingabout/

TimeRepublik. (2017). Learn more. Resource document. https://timerepublik.com/learn-more. Accessed 8 October 2017.

Travelife. (2017). About Travelife. Resource document. http://travelifecollection.com/about_travelife. Accessed 9 October 2017.

Veblen, T. (1899). The theory of the leisure class: An economic study of institutions. New York: MacMillan.

von der Weppen, J., \& Cochrane, J. (2012). Social enterprises in tourism: an exploratory study of operational models and success factors. Journal of Sustainable Tourism, 20(3), 497-511.

Winikoff, N. (2017, January 1). TimeRepublik, time banking, the sharing economy with Gabriele Donati. Vuepeer. Resource document. http://www.vuepeer.com/\#/blogs/timerepublik-time-banking-thesharing-economy-with-gabriele-donati. Accessed 10 February 2017.

World Tourism Organization. (2001). Global Code of Ethics for Tourism (A/RES/56/212). Geneva: UNWTO General Assembly. 